Trivent Publishing

(C) The Authors, 2016

Available online at http://trivent-publishing.eu/

Series Philosophy, Communication, Media Sciences

Volume The Modern and Contemporary Reception of Saint Gerard of Cenad

\title{
Dying for Christ on the Move: Representing the Martyrdom of Saints Lawrence, Gerard of Cenad, and Eugenia of Rome
}

\author{
Andrea-Bianka Znorovszky \\ Central European University, Medieval Studies Department, Hungary
}

\begin{abstract}
This paper is a case study on the visual representations of conversion and martyrdom in the lives of Saints Lawrence, Saint Gerard of Cenad, and Saint Eugenia. It focuses on the construction and the iconography of the holy body in relation to such themes as: conversion, torture, and death for Christ's sake. Furthermore, it aims to present the circulation and adaptation of iconographic patterns from the space of cult (Italy) to another space of worship (France).
\end{abstract}

\section{Keywords}

Conversion; martyrdom; iconography; Saint Lawrence; Saint Eugenia; Saint Gerard of Cenad; relics.

This is an Open Access article distributed in accordance with the Creative Commons Attribution Non Commercial (CC-BY-NCND 4.0) license, which permits others to copy or share the article, provided original work is properly cited and that this is not done for commercial purposes. Users may not remix, transform, or build upon the material and may not distribute the modified material (http://creativecommons.org/licenses/by-nc/4.0/) 
The thirteenth and fourteenth centuries witness an increase in the number of manuscripts and a rapid spread of collections which include a great variety of holy figures from early Christian martyrs, late tenthcentury martyrs, and penitent saints to holy women in disguise and many more. The lives of Christian martyrs represent a consistent part of some of the French Legenda Aurea and of other hagiographic collections such as the Angevin Legendary or the Speculum historiale. ${ }^{1}$ The lives are generally grouped according to the calendar year (Legenda Aurea), in a gendered way (Angevin Legendary) or in groups of holy figures (martyrs penitents, hermits). This implies the existence of iconographic correspondences that emphasize the concept of martyrdom and dying for Christ through various themes such as conversion, fleeing the world, promoting faith and so on. Furthermore, the positioning in the manuscripts permits a timeless, subtle, and permanent contact between the saints -- be that early Christian martyrs or later ones. It is a context of communication: one saint assisting at the other one's process and torture; it is as if all the lives become one and only martyrdom. In the following, the saint whose visual representations allow such correspondences is Saint Lawrence, whom in certain cases is close to Saint Eugenia and to Saint Gerard. This closeness is identifiable with regard to miniatures (Lawrence-Eugenia and Lawrence-Gerard), paintings (Lawrence- Eugenia), and cult/relics (Lawrence-Eugenia).

\section{Space and martyrdom}

Saints Eugenia, Lawrence and Gerard share some common elements that I call movement towards Christ. One of the first movements refers to the changing of space.

Saint Lawrence (225-258 AD), leaves Aragon, and dies as a martyr in Rome. ${ }^{2}$ His life concentrates on him leaving to Rome where he is ordained as a deacon. During Emperor Valerian, all church authorities were sentenced to death. The prefect of Rome issues an order that all church goods should be handed over to the state, while Lawrence hands them over to the poor. When asked to hand over the treasures, he presents the poor and the crippled as the treasures of the church. This gesture leads to his impending martyrdom. If we strictly analyze the concept of movement in the vita, Lawrence travels from Spain to Italy, Rome. In his case and Eugenia's, Rome becomes the space of their death and, implicitly, the space of their victory over paganism.

Saint Eugenia of Rome ( $† 258$ AD), the daughter of a Roman pagan family, hears Christians preaching and decides to leave her home. ${ }^{3}$ In order to enter a monastic community, whose abbot does not like women, she cross-dresses. Later, she becomes abbot of the monastery and is accused by a woman, Melanthia, of indecent behavior. In order to prove her innocence, she undresses in public and converts her

${ }^{1}$ Gail Ashton, The Generation of Identity in Late Medieval Hagiography (London and New York: Routledge, 2000). Christina Clever, "Saint and Relics" in Handbook of Medieval Culture vol. 3, ed. Albrecht Classen (Berlin and Boston: Walter de Gruyter Gmbh, 2015), 1543-1559. Jacques Le Goff, In Search of Sacred Time: Jacobus de Voragine and the Golden Legend (Princeton: Princeton University Press, 2014). Béla Zsolt Szakács, "The Holy Father and the Devils, or Could the Hungarian Angevin Legendary Have Been Ordered for a Pope?," in The Man of Many Devices, Who Wandered Full Many Ways..., ed. Balázs Nagy and Marcell Sebők (Budapest: Central European University Press, 1999), 52-60.

2 See, for instance, versions of Lawrence's vita in Speculum historiale, Ms. Arsenal 5080, folio 194r, Speculum historiale, Ms. Français 51, folio 31r, or Speculum historiale, Ms. Nouvelle acquisition française 15941, folio 66r, Paris, National Library of France.

${ }^{3}$ See, for instance, Speculum historiale, Ms. Arsenal 5080, folio 152v, Speculum historiale, Ms. Français 51, folio 26r, or Speculum historiale, Ms. Nouvelle acquisition française 15941, folio 61v, Paris, National Library of France or a translation in English by Agnes Smith-Lewis, "Select Narratives of Holy Women from the Syro-Antiochene or Sinai Palimpsest," Studia Sinaitica 10 (1900): 36-45. 
family to Christianity. Not only Eugenia, but also her father, Philip, who becomes a bishop, and two of her converted servants, Saints Prothus and Hyacinthus, die as martyrs. If we analyze the notion of movement inside the vita, one observes that Eugenia's family is sent to Egypt where she converts to Christianity, then, she goes to Rome where, after patronizing over a monastic establishment, she dies as a martyr. The episode of her identity revealing and that of her martyrdom are separated. Practically, in most of the French manuscripts, her vita is divided in two: a first part is focusing on her story until she reveals her identity; then, other saints' vitae are inserted in the manuscript, and, finally, follows Eugenia's martyrdom. This segmentation of her vita allows us to make various correspondences on the way movement towards martyrdom is generally viewed.

If we turn our attention to the life of Saint Gerard Sagredo (or Gerard of Cenad, Gerard of Csanàd) the concept of movement is the opposite. ${ }^{4}$ Gerard, an eleventh-century martyr, leaves Venice and dies in the Kingdom of Hungary. On a pilgrimage, he meets King Stephen of Hungary (975-1038) and becomes the tutor of the king's son, Prince Emeric (1007-1031). After Stephen's death, during a pagan uprising, Gerard dies a martyr's death. Gerard's movement is opposite to that of Eugenia and Lawrence; he leaves a Christianized territory, Italy, ending up promoting and converting pagans.

\section{Conversion and martyrdom}

The second and third movement towards Christ refer to the power of these saints when converting (pagans) and dying. There is a clear difference between the group of men and, the only woman, Eugenia, when promoting faith. Both Lawrence and Gerard are depicted in action. Gerard's gestures (Fig.1) indicate communication and preaching as he is conversing with King Stephen. ${ }^{5}$ The two characters are positioned antithetically in the miniature, the submission and humility of Gerard is indicated by the proximity to the king depicted on a throne, in a leading position. Here, Gerard is shown similarly to martyrs: in the position of confronting and offering explanations to a leader. ${ }^{6}$

\footnotetext{
${ }^{4}$ See, for instance, Imre Szentpéteri (ed.), Scriptores Rerum Hungaricarum (SSRH), vol. II (Budapest: Egyetemi Nyomda, 1938), 480-506. For other sources see, Martin Roos, "Izvoare istorica cu privire la Vita Gerardi," [Historical sources on the Vita Gerardi] in Filosofia Sfântului Gerard de Cenad in context cultural si biografic [The Cultural and Biographical Philosophy of Saint Gerard of Cenad], ed. Claudiu Mesaroş (Szeged: Jate Press, 2013), 23-29.

${ }^{5}$ Şerban Turcuş, Saint Gerard of Cenad or The Destiny of a Venetian around the Year One Thousand (Cluj-Napoca: Romanian Cultural Institute, Center for Transylvanian Studies, 2006), 11-22.

${ }^{6}$ Béla Zsolt Szakács, A Magyar Anjou Legendárium Képi Rendszerei [The Visual World of the Hungarian Anjou Legendary] (Budapest: Balassi, 2006), 180.
} 


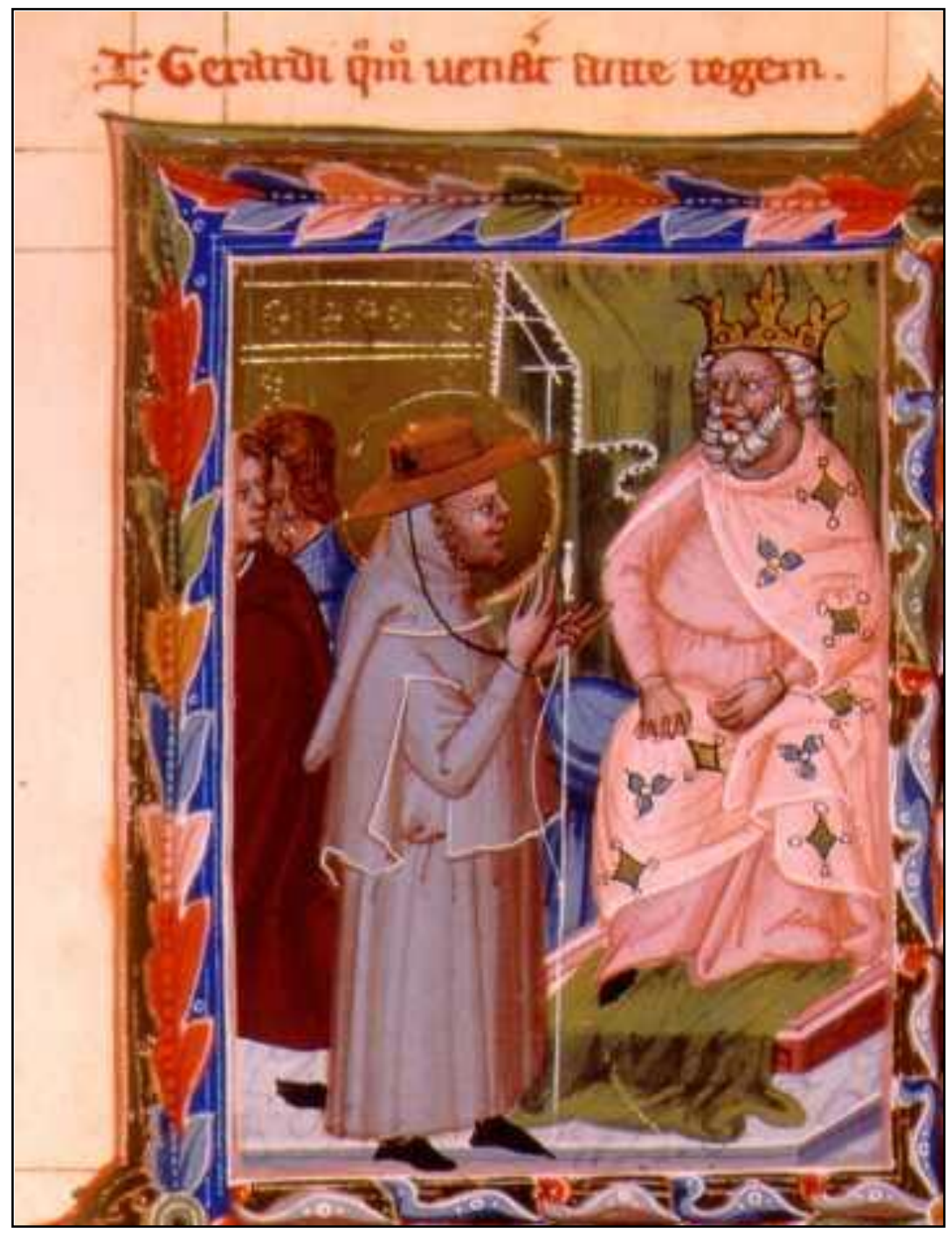

Fig. 1. Saint Gerard in front of King Stephen, fourteenth century Angevin Legendary, the Vatican, Vatican Library, Ms. Vat. lat. 8541, folio 68r.

Saint Lawrence is depicted helping the poor. Although his life indicates that he offered the church treasury to the people, the illuminations concentrate on him blessing the poor (Fig. 2) or feeding them (Fig. 3). The image of the community is represented in a different way in Saint Lawrence's case. Here, emphasis is laid on the lower stratum of society: the crippled, the poor, and the blind, in contrast to the religious community of Eugenia or the noble elite of Gerard. These episodes, then, are paired sometimes with Lawrence discussing with a king and being tortured. The gestures of his life as a deacon underline and indicate the reasons of the torture that is to follow. 


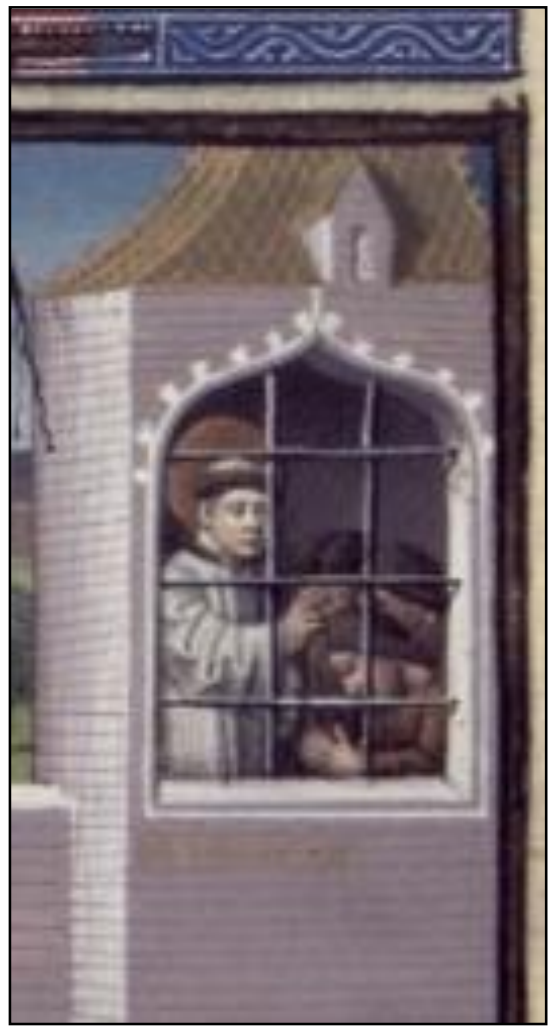

Fig. 2. The deeds of Saint Lawrence, 1463, François et collab. Speculum historiale, Paris, National Library of France, Français 51, folio 31r.

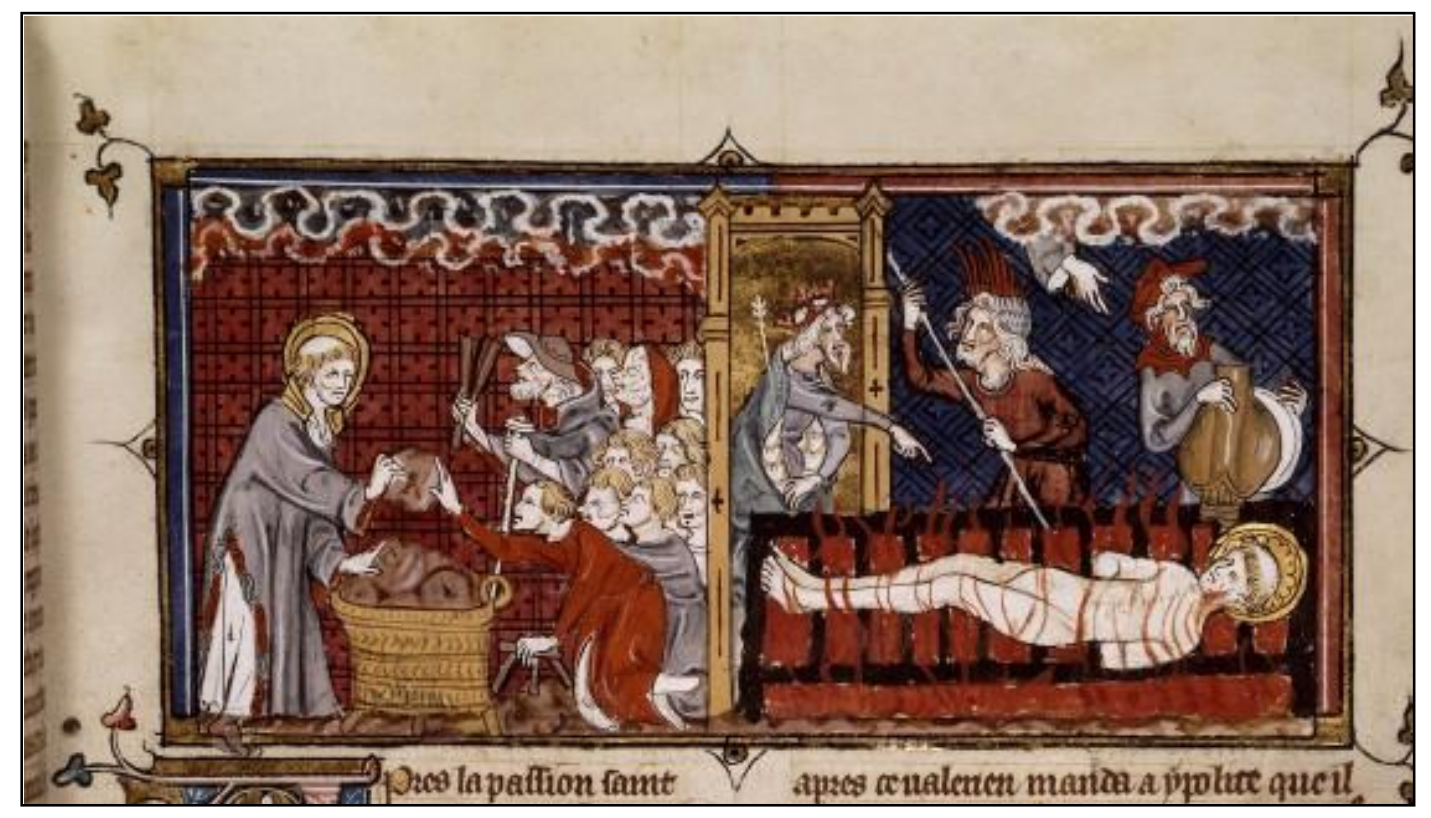

Fig. 3. The passion and the deeds of Saint Lawrence, 1355, Mahiet et collab., Speculum historiale, Paris, National Library of France, Arsenal 5080, folio 194r. 
Turning our attention to Saint Eugenia, she is depicted in movement amidst her converted group of nuns (Fig. 4) or when dying. In this last context, the saint's speech is more important in the torture scene: suffering together with words is against the idea of a passive femininity as the martyr's inaction becomes a sign of strength. In Fig. 5 we observe that the depiction includes several narrative episodes all related to Eugenia's torture. Her gestures indicate strength, when her hands are raised against the statue of Diana, or passive acceptance when killed similarly to Saint Lawrence.

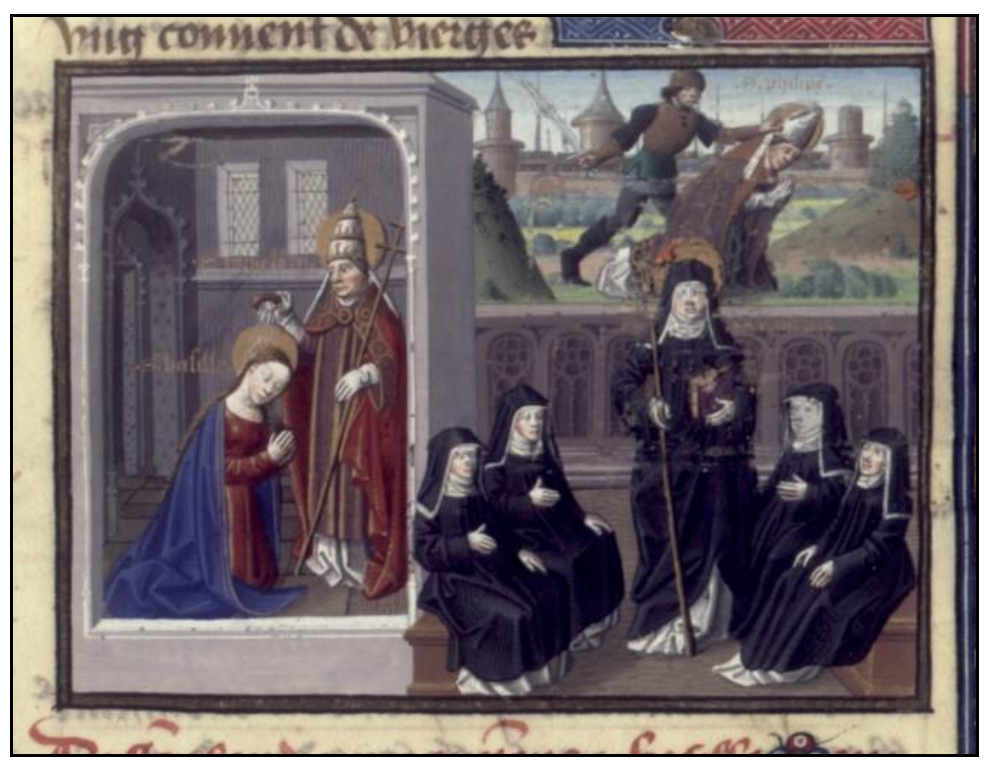

Fig. 4. Saint Eugenia as abbess (right), Baptism of Blasilla (left), Martyrdom of Philip (above) 1463, François et collab., Speculum historiale, Paris, National Library of France, Français 51, folio 3r.

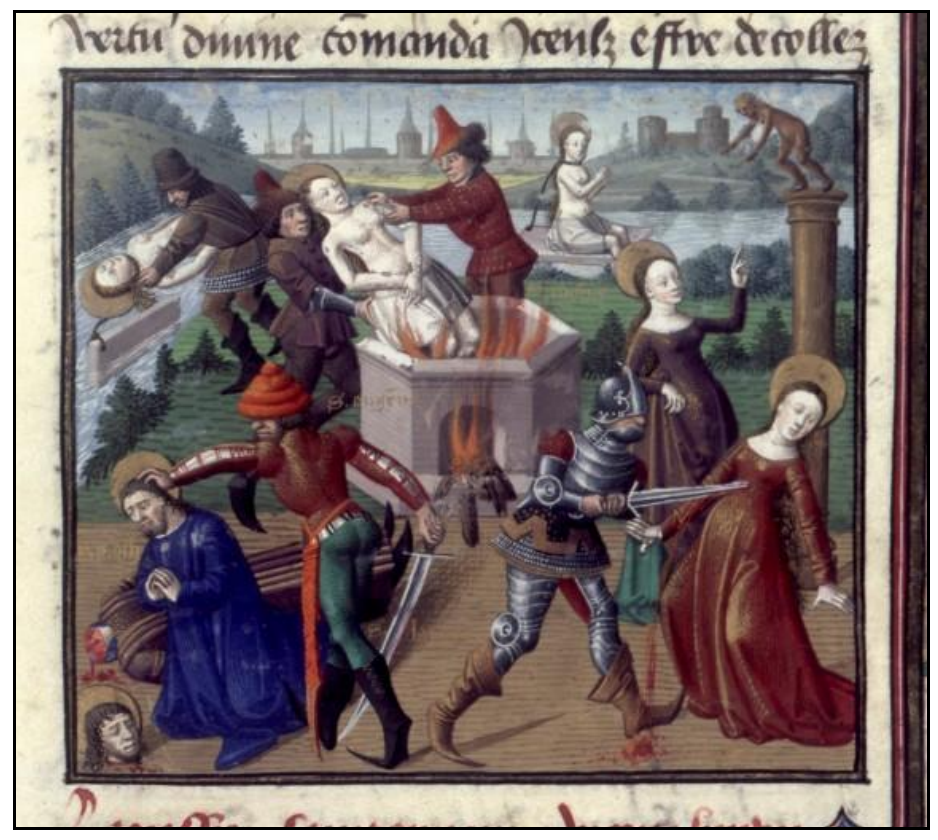

Fig. 5. The Passion of Saint Eugenia (together with Saints Prothus and Hyacinthus), 1463, François et collab., Speculum historiale, Paris, France, National Library of France, Français 51, folio 26r. 
There are some varieties concerning Eugenia's martyrdom episode(s). First of all, Eugenia evolves from being killed in the company of her eunuchs (Fig. 5) to being killed alone (Fig. 6). In this way, greater emphasis is laid on the saint herself and less on them as a group. Eugenia is depicted later in secular clothes, richly adorned.

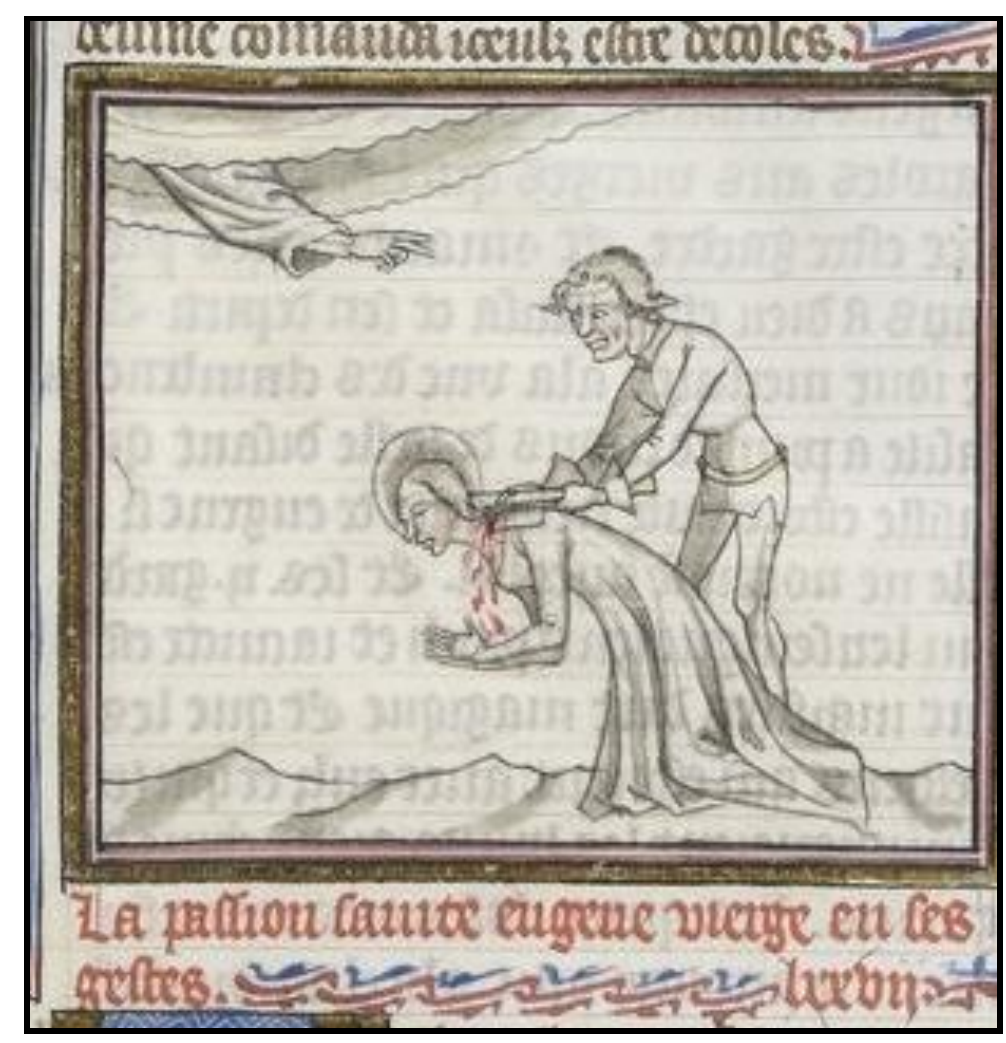

\section{Fig. 6. Martyrdom of Saint Eugenia, 1396, Speculum historiale Paris, National Library of France, Français 313, folio 184v.}

What is interesting about Eugenia is that she is paired in some cases with representations of Saint Lawrence, in France, but also Italy. In this sense, the Church of Bagnoro, Italy, had been dedicated to Saint Eugenia already as early as the eighth century ${ }^{7}$ or perhaps much earlier in the fourth-fifth centuries, ${ }^{8}$ possibly under the influence of Ravenna. ${ }^{9}$ Facing the viewer frontally, Eugenia is positioned on the right side of the Virgin, whereas Lawrence is situated on the left side on a relief above the portal (Fig. 7). ${ }^{10} \mathrm{I}$ consider it both interesting and provoking to hypothesize the possibility of a similar representation of Eugenia and Lawrence (perhaps) inside the Church of Bagnoro taking into consideration that the iфonographical typology of the Virgin is similar to a fresco inside the church.

${ }^{7}$ Carla Corsi Miraglia, "Le Pieve di Sant'Eugenia al Bagnoro," Bolletino d'informazione 35 (1982): 16-17.

${ }^{8}$ Angelo Tafi, La millenaria Pieve di S. Eugenia al Bagnoro (Arezzo: Calosci-Cortona, 1991), 31.

${ }^{9}$ Fabio Gabbrielli, Romanico aretino. L'architettura protoromanica e romanica religiosa nella Diocesi medioevale di Arezzo (Florence: Salimbeni, 1990), 47.

${ }^{10}$ Gabbrielli, Romanico aretino, 74. Miraglia, "Le Pieve di Sant'Eugenia” 19. Fabio Gabbrielli, Romanico aretino. L'architettura protoromanica e romanica religiosa nella Diocesi medioevale di Arezzo (Florence: Salimbeni, 1990), 73. 


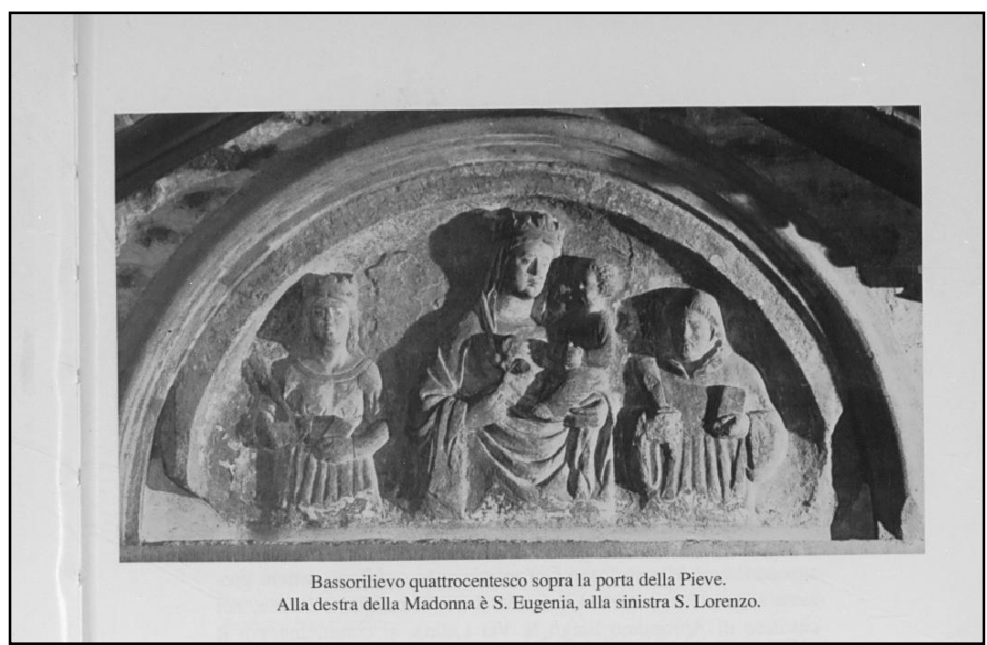

Fig. 7. The Virgin Mary with Saint Eugenia (right) and Saint Lawrence (left), Bagnoro, Italy (reproduced in Angelo Tafi, La millenaria Pieve di S. Eugenia al Bagnoro (Arezzo: Calosci-Cortona, 1991)

In France, besides the cult of Saint Eugenia, Saint Lawrence was also venerated and highly appreciated. It was on the $18^{\text {th }}$ of May, 923 when Gaudry, bishop of Auxerre, on his return from Rome brought with him two precious relics, one of Saint Eugenia and one of Saint Lawrence. ${ }^{11}$ Offered to Gaudry by Pope John X after his visit to Rome, Saint Eugenia's relics were divided and sent to three religious establishments: the abbey of Saint-Germain, ${ }^{12}$ the cathedral of Auxerre, and, most to Varzy, where, starting from the fifth century, a church had been supposedly dedicated to her by Saint Germain of Auxerre. ${ }^{13}$ Relics and depictions of Saint Eugenia can be found in Auxerre, Vézelay, Varzy, and Neveres, all closely located to each other. ${ }^{14}$

One of the earliest surviving representations of Eugenia in France is found in the Cathedral of Nevres (Fig. 8). Twelfth-century fresco episodes from the life of Saint Eugenia seem to have once covered the cathedral on the right side when entering the door of Saint John. Unfortunately, only five martyrdom episodes have survived in a better condition. ${ }^{15}$ These episodes depict Saint Eugenia in front of the emperor, tied to a stone and floating on water, with hands tied in the middle of flames, and receiving bread from Christ while in prison. In both cases Eugenia is depicted with hands tied, floating on water, and receiving bread in prison. All these episodes are common to the manuscript representations detailed above.

${ }^{11}$ Paul Guérin, Les Petits Bollandistes. Vies des saints, tome 14 (Paris: Bloud et Barral, Libraires-Éditeurs, 1885), 468. See also Augustin Crosnier, Hagiologie Nivernaise ou Vies des saints et autres pieux personages qui ont édifié le diocese de nevers par leurs vertus (Nevers: Imprimerie de L.-M., 1858), 149-150.

12 On the existence of Eugenia's relics in this religious establishment see Henry Waast, Histoire de l'abbaye de Saint-Germain d'Auxerre (Auxerre: C. Gallot Libraire, 1853), 576-577.

${ }^{13}$ Guérin, Les Petits Bollandistes, 468. Louis Serbat, "Varzy" Congrès Archéologique de France (Paris: A. Picard, Caen: H. Delesques, 1916), 401. Abbé Le Boeuf, Mémoires concernant l'histoire civile et ecclésiastique d'Auxerre (Paris: Didron Libraire, 1848), 232.

${ }^{14}$ For Luxeuil, France, as center of her cult, see Dictionnaire d'Histoire et de Géographie ecclésiastique (1962), 1375.

${ }^{15}$ Guérin, Les Petits Bollandistes, 467. See also Crosnier, Hagiologie Nivernaise, 151-152. Jaques Loquin, Nevers et Moulins (Paris: Libraire Renouard, 1913), 26. 


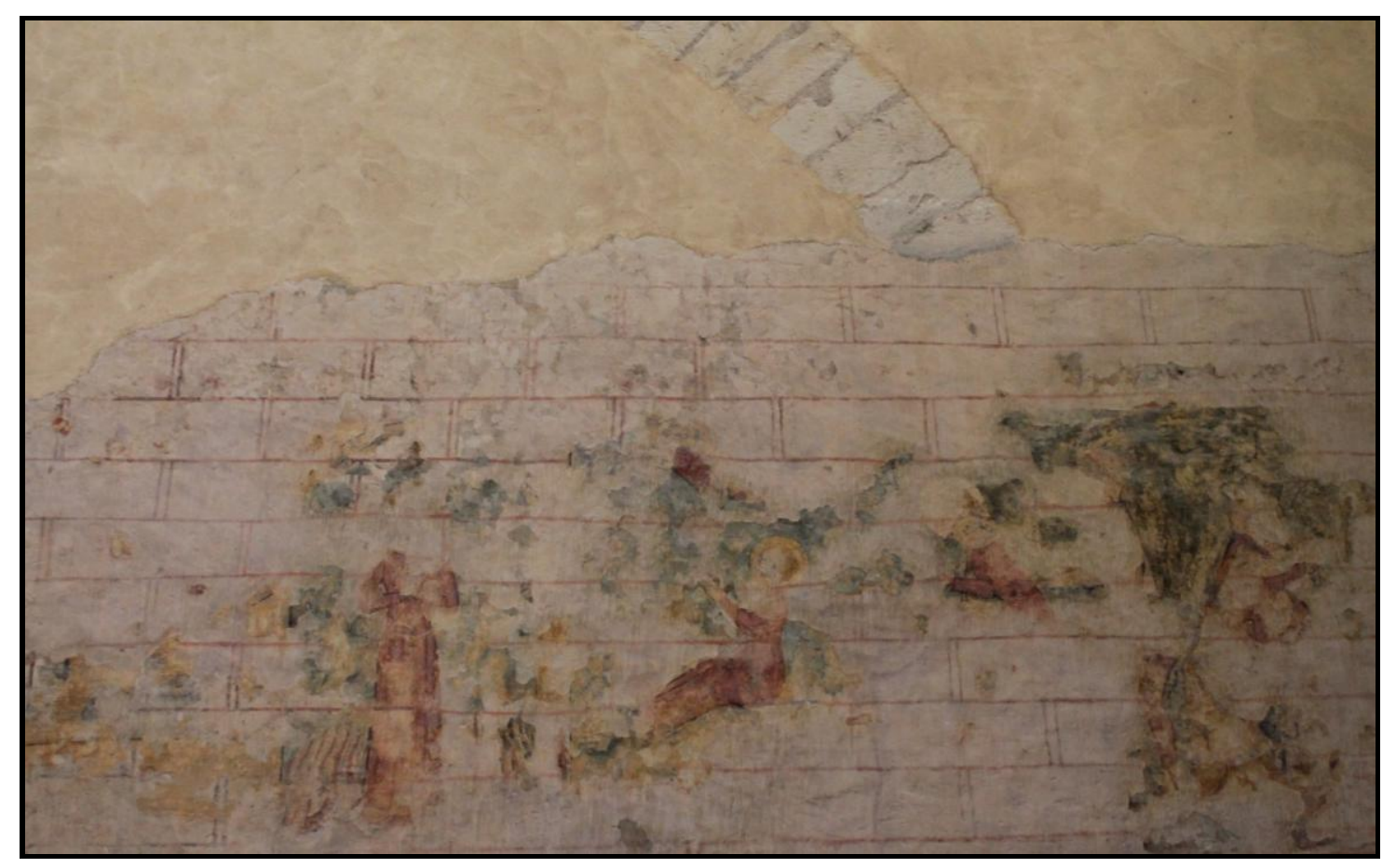

Fig. 8. Saint Eugenia martyrdom episodes, thirteenth century Church of Saint Cyr and Saint Julitte, Nevers, Paris

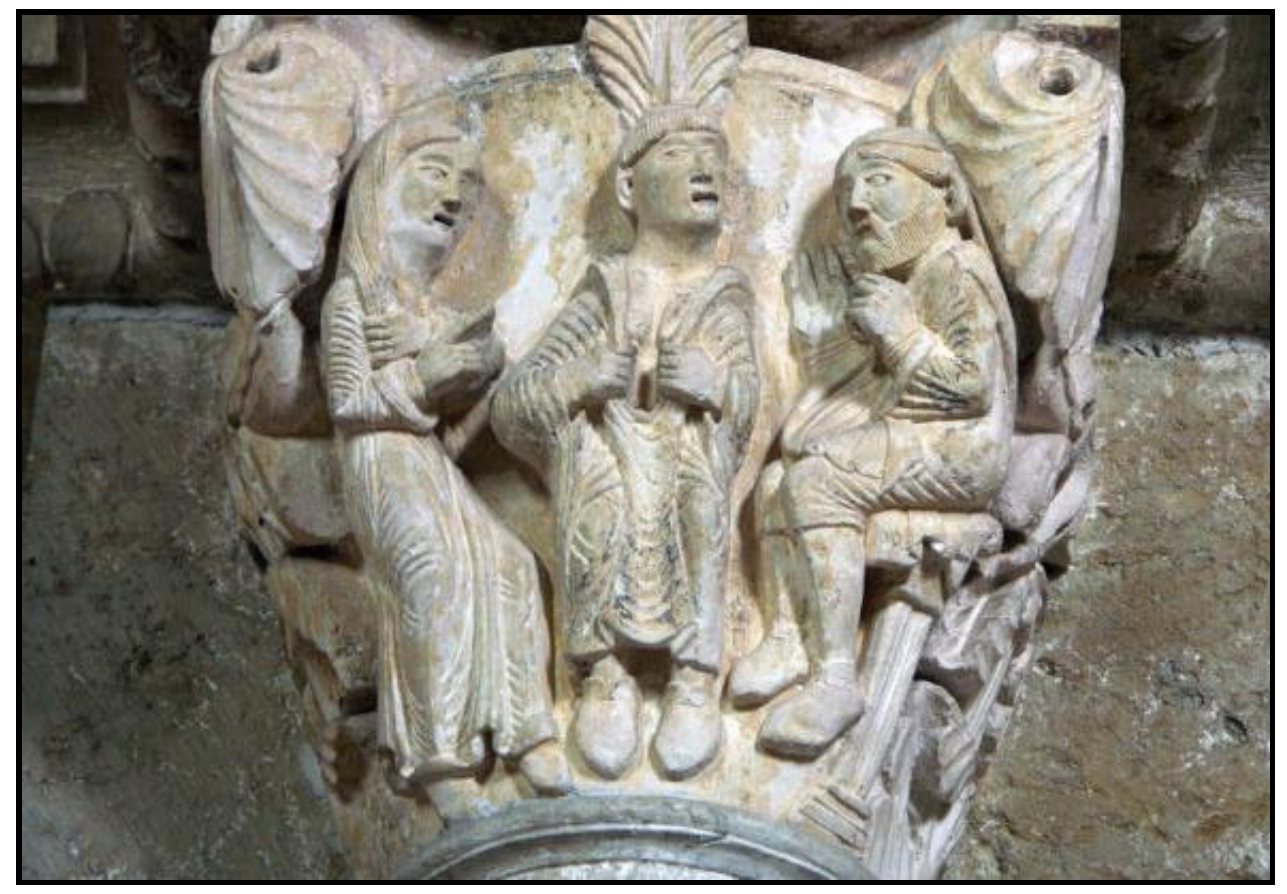

Fig. 9. Saint Eugenia of Rome revealing her identity, twelfth century Church of Saint Magdalene, Vézelay, France 
Another early representation of Eugenia is a twelfth-century relief from Vézelay (Fig. 9), situated on the northern pillar of the nave. ${ }^{16}$ It focuses on Eugenia revealing her identity. Positioned between her father and Melanthia, Eugenia reveals her identity in order to prove her innocence. Her innocence is emphasized in Vézelay, while in Nevers, her martyrdom (and possibly other episodes of her life cycle including that of her trial). This underlines the fact that Eugenia's iconography in Burgundy is not fixed but rather fructuous. It seems to belong to a network of representations of religious establishments that possessed either relics of her or have been influenced by the proximity of places of worship/cult.

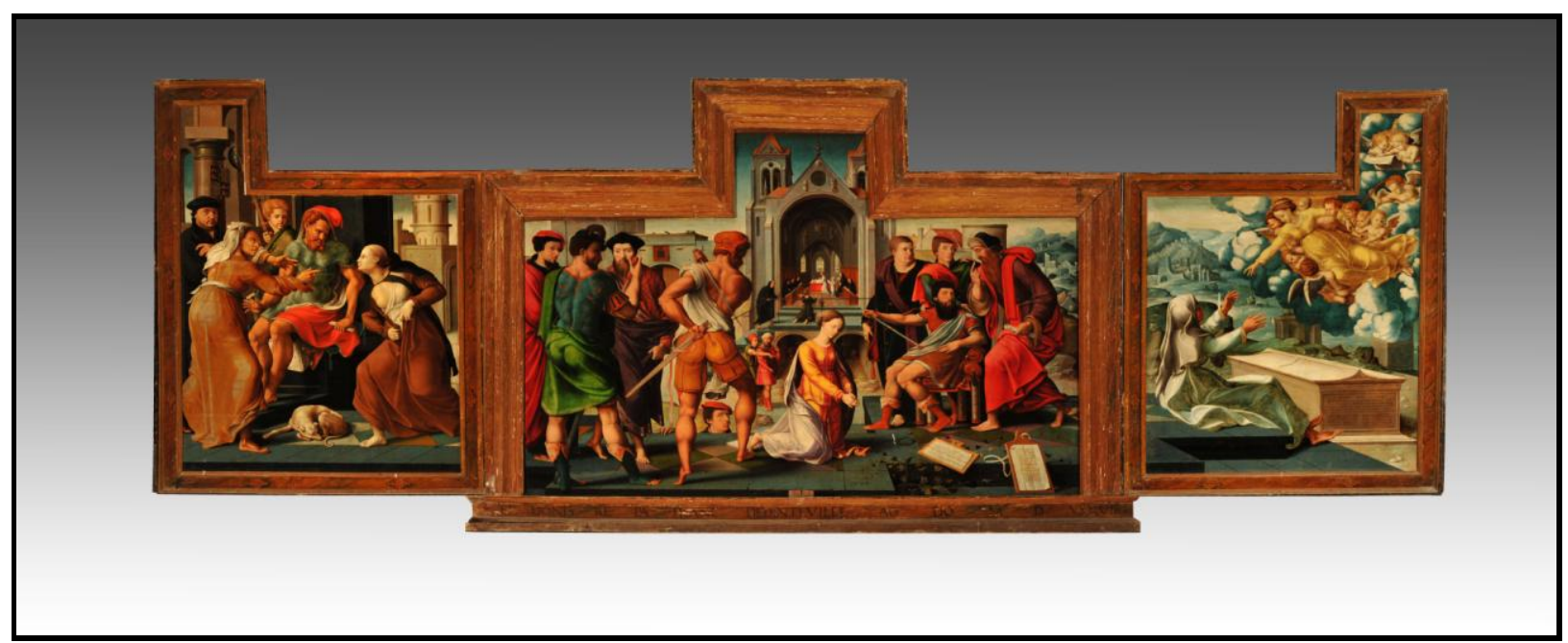

Fig. 10. The Martyrdom of Saint Eugenia, sixteenth century Bartholomeus Pons, Church of Saint-Pierre- ès-liens, Varzy, France

According to Kirk Ambrose, a Church dedicated to Saint Eugenia in Varzy had been decorated with representations of Eugenia. ${ }^{17}$ Unfortunately, it was left in ruins during the French Revolution and there are no surviving depictions. What has survived is a sixteenth-century triptych (Fig. 10) that concentrates on three important episodes of her life: identity revealing, martyrdom, and saint in heaven; while the other side of the panels depicts Saints Stephen and Lawrence (Fig. 11). ${ }^{18}$ The triptych was donated in 1537 by François II de Dinteville to the Collegiale Sainte- Eugénie de Varzy and transferred later to the Church of Saint-Pierre-ès-liens. In the seventeenth century, it was dismembered and identified as such in the nineteenth century by a Parisian artist who found the two side panels and put them together. ${ }^{19}$

The episode of Eugenia's revealing not only survived twelfth-century Vézelay, but seems to be still important in other visual representations of her. The donor of this triptych, François II de Dinteville, was bishop of Auxerre starting from 1530 until his death and had a particular affinity to early Christian topics so much that his portrait was included in the representation. ${ }^{20}$ In my opinion, besides the bishop's preferences, the triptych is a testimony that the bishopric of Auxerre appreciated and, still, promoted

\footnotetext{
${ }^{16}$ Jean-Luc Flohic (ed.), La patrimoine de la basilique de Vézelay (Charento-le-pont: Editions Flohic, 1999), 106.

${ }^{17}$ Kirk Ambrose, The Nave Sculpture of Vézelay: the Art of Monastiv Viewing (Toronto: Pontifical Institute of Medieval Studies, 2006), 43. Serbat, "Varzy," 414.

${ }^{18}$ La Peinture en Bourgogne au XVIe siècle (Dijon: Musée des Beaux-Arts de Dijon, 1990), 108-109. Serbat, "Varzy," 410 - 413- also mentions the presence of the Benedictine monks in the background. Guérin, Les Petits Bollandistes, 467.

19 Jacques Thuillier, "Dismembered Works of Art-French Painting," in An illustrated inventory of famous dismembered works of art. European painting with a section on dismembered tombs in France (Louvain: Ceuterick 1974), 89-90.

${ }^{20}$ Elizabeth A. R. Brown, "The Dinteville Family and the Allegory of Moses and Aaron before Pharaoh," Metropolitan Museum Journal 34 (1999): 73.
} 
Eugenia and also Lawrence's cult. Furthermore, the depiction of Saint Lawrence on the external side of the panels might be a testimony and a reminder of Gaudry's transfer of the relics of both Saints Lawrence and Eugenia. ${ }^{21}$ The proximity of Saint Lawrence to Eugenia reminds of the Bagnoro representation, but also indicates an existing pattern that could have been transferred from Italy to France. On the first hand, the manuscript illuminations (Fig. 3) concentrate in some cases on the same martyrdom pattern: the saint is tortured in front of an emperor. The painting from Varzy fits in this case meaning that a greater emphasis is laid on the character's suffering for Christ and less on the conflict with the emperor. This episode represents the victory of the martyr through death.

It is again in a martyrs' context that Lawrence appears, but this time in a different collection of holy lives, namely, the Anjou Legendarium. Here, his representations (Fig. 12) are preceded by those of Saint Stephen, a protomartyr and deacon, and Saint Vincent, deacon. The Anjou Lawrence is depicted as a pious deacon even when tortured by placing his hand over his chest. ${ }^{22}$

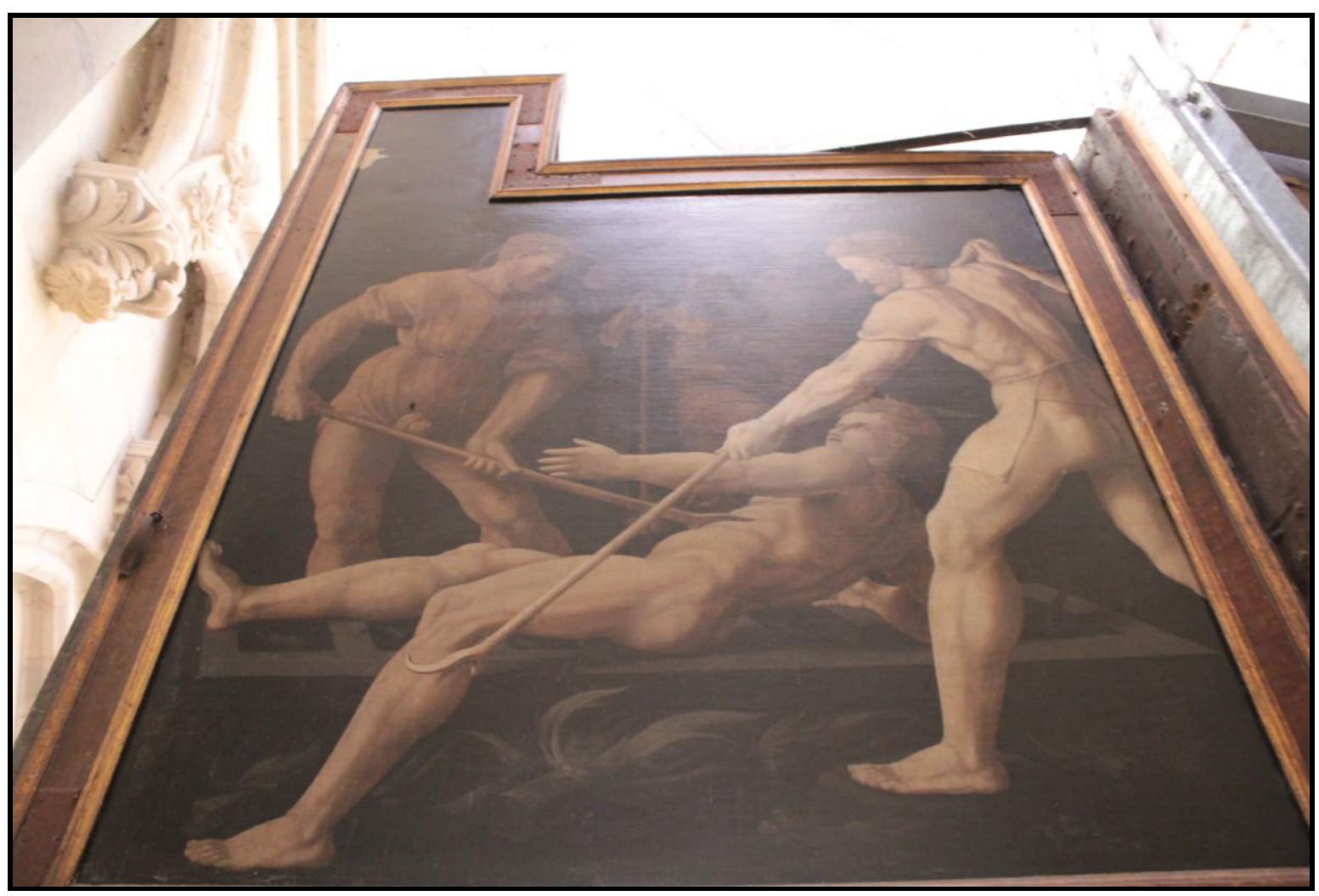

Fig. 11. Martyrdom of Saint Lawrence, sixteenth century Bartholomeus Pons, Church of Saint-Pierre- ès-liens, Varzy, France

${ }^{21}$ Crosnier, "Hagiologie Nivernaise," 292.

22 Szakács, A Magyar Anjou Legendárium, 179. 


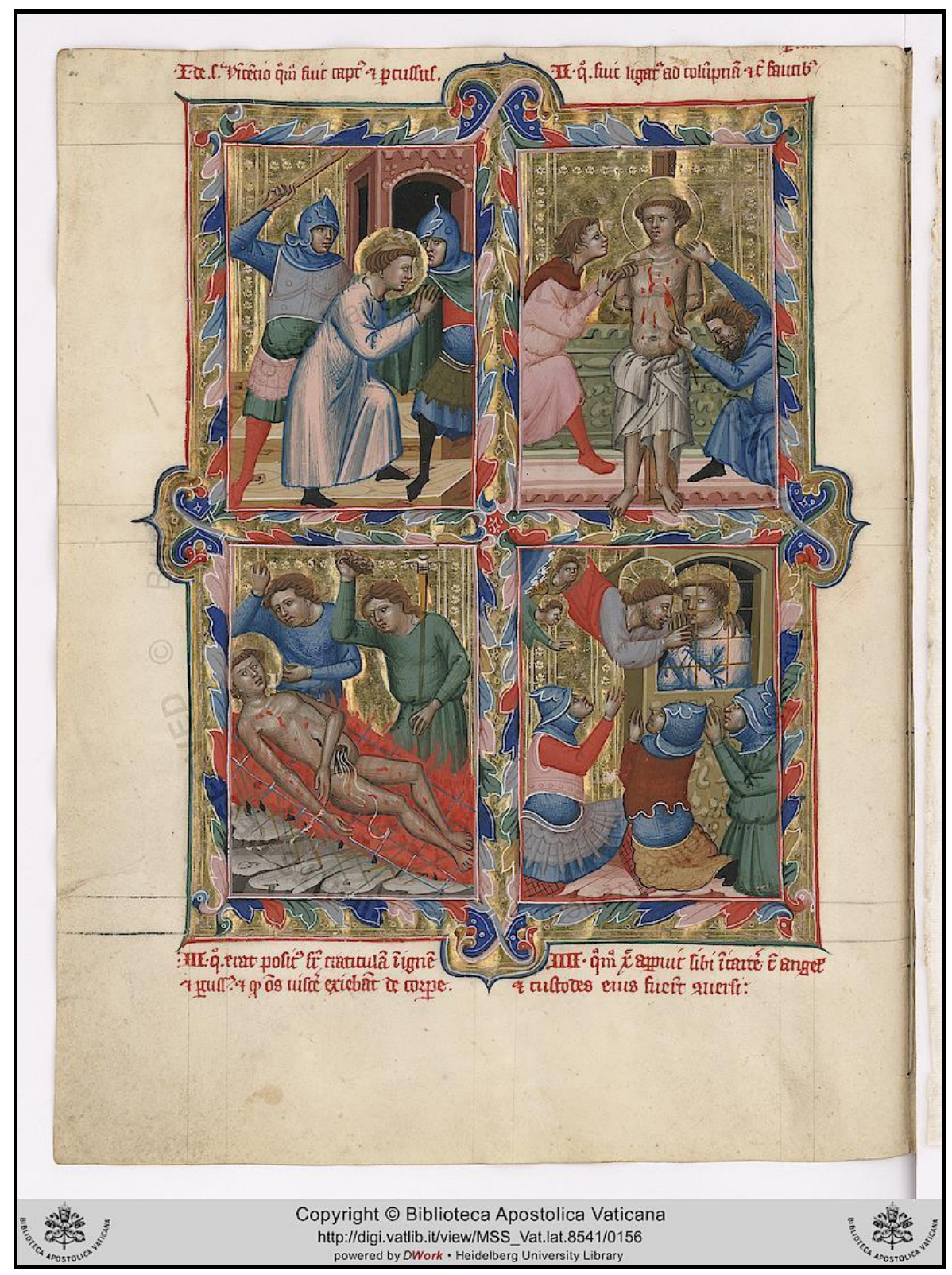

Fig. 12. Martyrdom of Saint Lawrence, fourteenth century, Angevin Legendary the Vatican, Vatican Library, Ms. Vat. lat. 8541, folio 50v.

\section{The Martyrdom of Saint Gerard}

Turning our attention to the miniatures concerning the martyrdom of Saint Gerard, there is one thing that strikes the viewer, namely, the less violence when representing his martyrdom in comparison to Lawrence and Saint Eugenia. Among this group of three, Saint Gerard is the only one whose torture episode does not reveal the naked body. Both Eugenia and Lawrence are tortured and depicted undressed during torture: Eugenia floats on the water and is burned similarly to Lawrence, in opposition to Gerard (Fig. 13) who is depicted while supposedly attacked by a group of pagans and then represented dead after thrown down from Mount Gellert. Saint Gerard belongs to the group of the church elite; he becomes the bishop of the Kingdom of Hungary converted to Christianity, in a period when the undressing of the martyr does not bear the same significance as in the case of the early martyrs. Here, the clothes of the saint emphasize 
the triumph of the bishop over paganism. But it is not only the triumph of the bishop, it is also the triumph of the Church over the heretics as Gerard is hierarchically connected to other martyr church figures of the Anjou Legendary such as: Saints Donatus, Stanislaus, and Thomas, all of them martyr bishops.

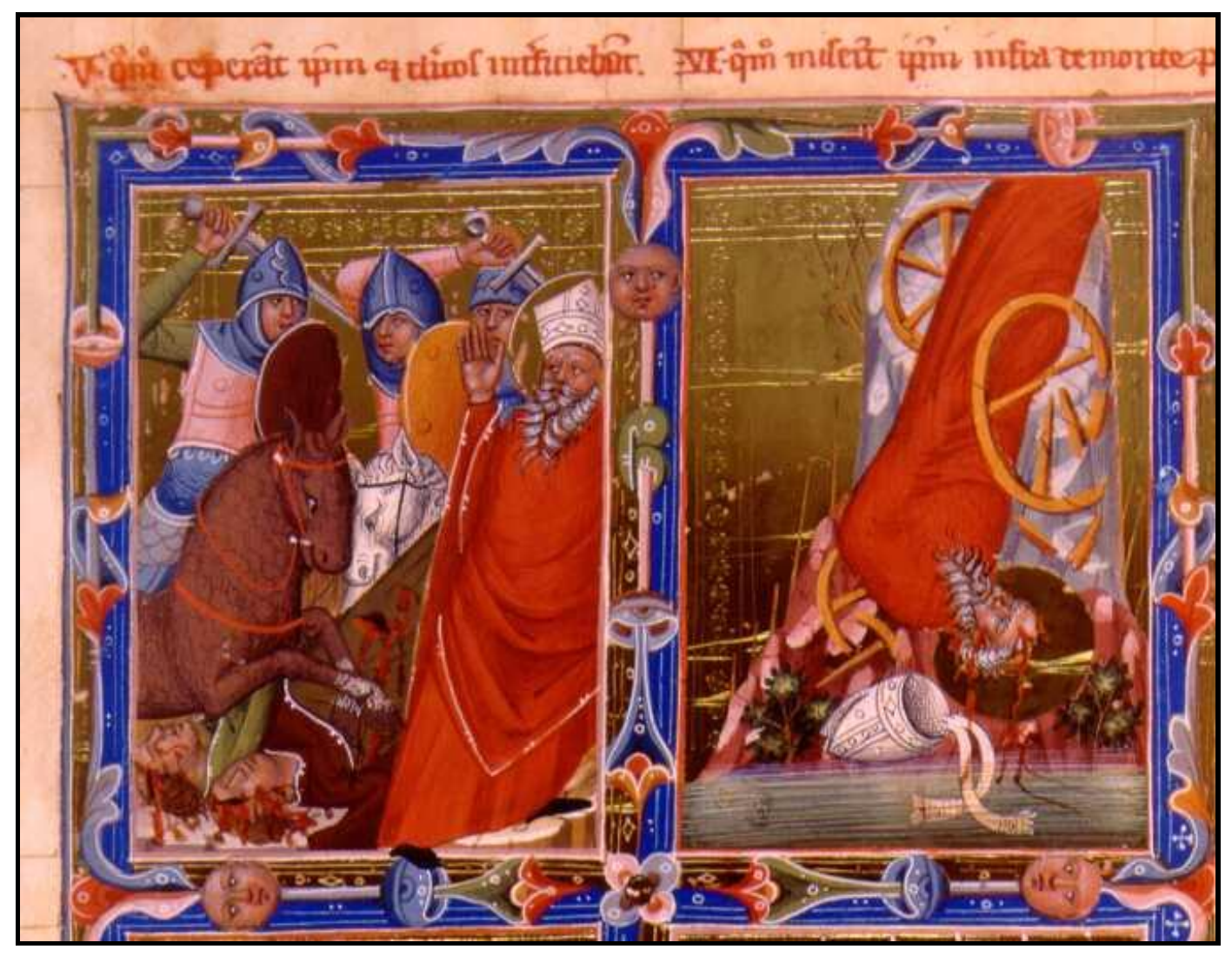

Fig. 13. The Martyrdom of Saint Gerard, fourteenth century, Angevin Legendary the Vatican, Vatican Library, Ms. Vat. lat. 8541, folio 69v.

If we analyze the miniatures concentrating on martyrdom in the Anjou Legendary, it becomes clear that Saint Gerard's is less detailed and occupies only two narrative episodes in comparison to the early deacon martyr Lawrence (Fig.12) whose torture is presented in four episodes. ${ }^{23}$ If in the case of the early martyrs, their captivity, torture, and death occupies most of the visual narrative, in Gerard's case, the emphasis is laid on his conversion of the king, on tutoring, preaching, and less on his death.

There are differences in the movements and different movements of these characters when gaining sanctity:

1. All of them leave a space that is more or less familiar to them in order to convert/confess faith; in all of the cases conversion leads to martyrdom.

2. The holy men are close to a leading figure such as Pope Sixtus (Lawrence) or Stephen, the King of Hungary (Gerard). Both of them are representatives of the religious elite: Lawrence is a deacon and Gerard is a bishop. With regard to Eugenia, it is important to mention that she becomes the leader of a religious community, meaning that probably she must have been under the protection of a bishop.

\footnotetext{
${ }^{23}$ Szakács, A Magyar Anjou Legendárium, 97-102.
} 
3. All of the saints move towards people of different hierarchies and genders: the poor (Lawrence), women (Eugenia), and the elite (Gerard).

4. Lawrence and Eugenia are early Christian martyrs who apparently died in the same year, hence the possible iconographical connection between the two in Italy and the transfer of this pattern of veneration into France.

5. Gerard is positioned in a later fourteenth-century manuscript that concentrates mostly on the lives of holy men. This permits the existence of iconographical connections between the various types of martyrs: early Christian ones or bishop martyrs: both of them died for their faith. 